\title{
Efektivitas Bioinsektisida Daun Eceng Gondok (Eichhornia crassipes) Terhadap Kematian Ulat Grayak (Spodoptera litura) Dan Biomassa Bayam Merah (Alternanthera amoena Voss)
}

\section{Bioinsecticide Effectiveness (Eichhornia crassipes) On The Death Of The Grayak (Spodoptera litura) And Biomass Of Red Spinach (Alternanthera amoena voss)}

\author{
T. Antonia Bilafa ${ }^{1}$, I.A.K. Pramushinta ${ }^{2}$ \\ Prodi Biologi Fakultas Sains Teknologi Universitas PGRI Adi Buana Surabaya \\ Email: theresiabilafa24@gmail.com ${ }^{1}$ Iak.pramushinta@unipasby.ac.id ${ }^{2}$
}

\begin{abstract}
Abstrak
Pemberian insektisida nabati berasal dari ekstrak daun enceng gondok untuk melihat tingkat kematian pada ulat grayak pada tanaman bayam merah. Analisis yang diamati dari jumlah daun dan produksi tanaman bayam merah, Perlakuan insektida alami menggunakan konsentrasi P0 (0\%), P1 (5\%), P2 (10\%) dan P3 (15\%). Analisis penelitian menggunakan Rancangan Acak Lengkap (RAL) dengan 4 perlakuan dan 6 kali ulangan, data yang diperoleh dianalisis menggunakan uji ANNOVA dan uji Duncan. Hasil penelitian menunjukkan bahwa mempersembahkan insektisida nabati pada ektrak daun eceng gondok memberikan pengaruh nyata $(\mathrm{P}<0,05)$ pada jumlah kematian ulat grayak, pertumbuhan tanaman bayam merah (jumlah daun) dan hasil produksi tanaman bayam merah. Hasil analisis uji Duncan bahwa pada perlakuan P3 (15\%) berbeda nyata dengan analisis lainnya.
\end{abstract}

Kata kunci: bioinsektisida, eceng gondok, ulat grayak, pertumbuhan, produksi, tanaman sawi.

\begin{abstract}
The application of vegetable insecticides derived from water hyacinth leaf extracts was used to determine the mortality rate in armyworms on red spinach plants. The analysis observed from the number of leaves and production of red spinach plants, natural insectide treatment used concentrations of P0 (0\%), P1 (5\%), P2 (10\%) and P3 (15\%). The research analysis used a completely randomized design (CRD) with 4 treatments and 6 replications, the data obtained were analyzed using the ANNOVA test and the Duncan test. The results showed that presenting a plant-based insecticide on water hyacinth leaf extract had a significant effect $(P<0.05)$ on the number of armyworm mortality, red spinach plant growth (number of leaves) and production of red spinach. The results of the Duncan test analysis showed that the P3 treatment (15\%) was significantly different from other analyzes.
\end{abstract}

Keywords: bioinsecticide, water hyacinth leaf extract, armyworm caterpillar, growth, yields, mustard plants.

\section{PENDAHULUAN}

Bayam merah (Alternanthera amoena Voss) merupakan salah satu jenis sayuran yang banyak disukai masyarakat untuk dikonsumsi karena kandungan nutrisinya yang cukup tinggi. Budidaya bayam merah pun cukup mudah dilakukan. Keuntungan ini memberikan peluang yang besar untuk melakukan usaha agribisnis bayam (Wachjar dan Anggayuhlin, 2013).

Kendala utama yang membatasi produktifitas bayam merah di daerah tropis yaitu banyaknya organisme penggangu tanaman (OPT) berupa hama dan penyakit potensial yang dapat menyerang dan menurunkan produksi bayam, bahkan tanaman dapat gagal panen bila tidak ada pengendalian hama. Hama yang sering menyerang bayam adalah ulat grayak (P.S. Ajiningrum dan I.A.K. Pramushinta, 2017).

Ulat Grayak atau Spodoptera litura, merupakan serangga hama yang menyerang tanaman budidaya pada fase vegetatif dengan memakan daun tanaman muda hingga tersisa tulang daun dan pada fase generatif yakni memakan polong-polong muda (Budi et al., 2013). Serangga ini, menyerang tanaman yang terdapat di banyak negara seperti Indonesia, India, Jepang, Cina, dan negara- negara lain di Asia Tenggara (Sintim et al., 2009). 
Pengendalian hama ini pada umumnya masih menggunakan insektisida kimia sintetik (Razak et al., 2014), sehingga dapat memuncukan organisme baru yang lebih tahan terhadap insektisida (Suharsono dan Muchlish, 2010). Penggunaan pestisida nabati diharapkan menjadi salah satu insektisida alternatif yang dapat menghindarkan resistensi dan resurgensi pada hama serangga (Balfas dan Willis, 2009).

Insektisida nabati merupakan pestisida yang mengandung bahan aktif tunggal atau majemuk yang dapat berfungsi sebagai penolak, anti fertilitas (pemandul), pembunuh organisme pengganggu tanaman, mengurangi pencemaran lingkungan, serta lebih murah dibandingkan dengan pestisida kimia (Wiratnoetal., 2015). Tanaman yang dapat dijadikan pestisida alami adalah tanaman eceng gondok (Eichhornia crassipes) dikarenakan daun eceng gondok memiliki kandungan senyawa flavonoid, steroid dan tanin jika di ekstraksi menggunakan metanol (Wijaya et al. 2016).

\section{METODE PENELITIAN}

Alat dan Bahan

Alat yang digunakan adalah: destilator, oven dan cawan uap. Adapun bahan penelitian sebagai berikut: daun eceng gondok, metanol dan ulat grayak 192 ekor.

\section{Metode Penelitian}

Penelitian dilakukan di Laboratorium Biologi Dasar dan Green House, Fakultas
Sains dan Teknologi, Universitas PGRI Adi Buana Surabaya. Penelitian ini menggunakan metode Rancangan Acak Lengkap (RAL) dan metode eksperimen dengan berbagai konsentrasi ekstrak daun eceng gondok yakni $0 \%, 5 \%, 10 \%, 15 \%$ dengan ulangan sebanyak 6 kali. Penelitian diawali dengan pembuatan ekstrak daun eceng gondok dengan menggunakkan metode meserasi yakni dengan perbandingan eceng gondok dan metanol adalah 1:5 kemudian dilakukan proses destilasi dengan desikator dan pengeringan menggunakan oven hingga mendapatkan hasil ekstrak kering. Ekstrak kemudian diencerkan dengan perbandingan ekstrak kering dan aquades sesuai perlakuan. Kemudian ekstrak diberikan kepada ulat grayak dan diamati selama 24 jam bertujuan untuk mengamati mortalitas pada tanaman bayam merah dengan pengulangan 5 kali untuk mengamati produktivitas tanaman. Hasil analisis mortalitas ulat grayak dihitung menggunakan perangkat lunak SPSS For Windows 22 dan dapat dilihat pada Tabel 1.

\section{HASIL DAN PEMBAHASAN}

Penelitian yang dilakukan menunjukan hasil bahwa pemberian bioinsektisida ekstrak daun eceng gondok (Eichhornia crassipes) dengan beberapa perlakuan memberikan pengaruh yang signifikan $(\mathrm{P}<0,05)$ terhadap mortalitas ulat grayak (spodoptera litura) dapat dilihat pada Gambar 1. 


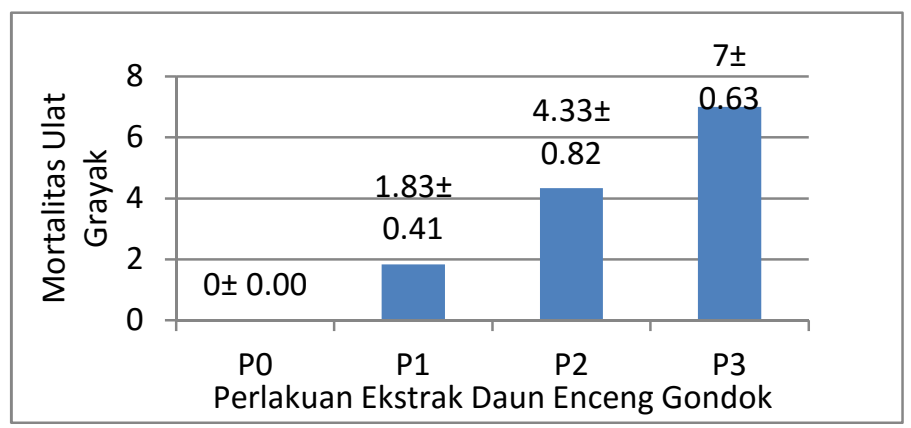

Gambar 1. Diagram mortalitas ulat grayak (Spodoptera litura) setelah diberikan perlakuan bioinsektisida ekstrak daun eceng gondok (Eichhornia crassipes)

Pada hasil uji Anova yang dilakukan menunjukkan bahwa berpengaruh secara signifikan terhadap pertumbuhan tanaman bayam merah sehingga dilakukan uji Duncan bioinsektisida daun eceng gondok dapat efektif membunuh ulat grayak pada tingkat konsentrasi 15\%. Pada gambar diagram 1. dapat diketahui bahwa setiap perlakuan yang memiliki konsentrasi berbeda berpengaruh terhadap jumlah kematian ulat grayak. Tingkat kematian ulat grayak meningkat seiring dengan tingkat konsentrasi yang meningkat pula. Kematian tertinggi terdapat pada $\mathrm{P} 3$, dikarenakan pada P3 memiliki kandungan senyawa kimia tanin , steroid dan flavonoid tertinggi dimana fungsi tanin adalah sebagai anti-feedant bagi serangga dimana bahan aktif ini bersifat pahit, sehingga serangga cenderung tidak memakan daun yang terasa pahit (Febriyanti, N., \& Rahayu, D. 2012).

Senyawa steroid merupakan senyawa yang dapat bertindak sebagai anti -feeding terhadap serangga dan menghambat kerja enzim menyebabkan penurunan kerja alat pencernaan dan penggunaan protein (Muta'ali \& Purwani, 2015). Serta sernyawa flavonoid yang dapat menjadi racun perut bagi serangga, karena ketika flavonoid masuk kedalam tubuh larva melalui makanan maka alat pencernaannya akan terganggu dan menyebabkan kematian (Cahyadi,R, 2009). Flavonoid juga dapat menghambat pertumbuhan dan bekerja sebagai inhibitor pernafasan (Ramayanti, 2017). Analisis jumlah daun dapat dilihat pada Gambar 2.

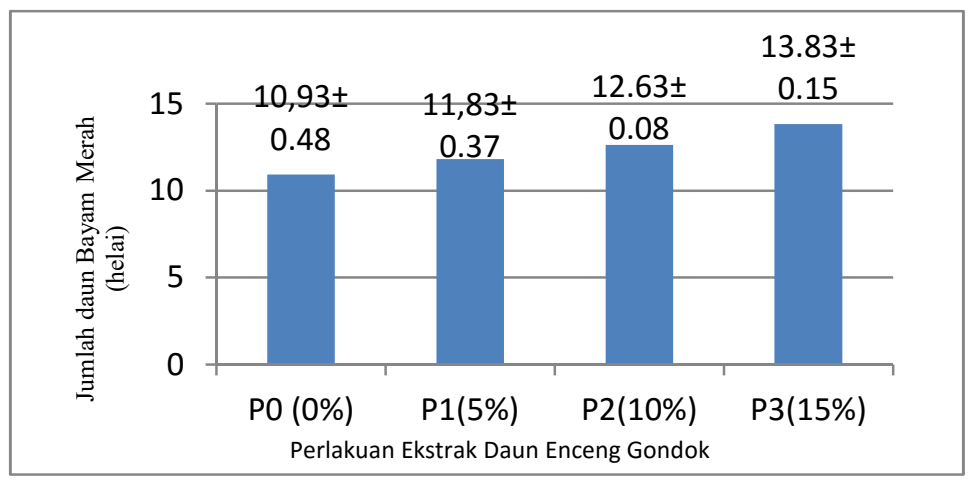

Gambar 2. Diagram jumlah daun tanaman bayam merah (Althernanthera amoena $\mathrm{V}$ ) setelah diberikan perlakuan bioinsektisida ekstrak daun eceng gondok (Eichhornia crassipes)

Berdasarkan hasil penelitian diketahui bahwa setiap perlakuan dapat menimbulkan pertambahan jumlah daun tanaman yang berbeda-beda. Perlakuan yang paling optimum yaitu bioinsektisida ekstrak daun eceng gondok pada konsentrasi P3 (15\%) 
yang hasilnya lebih tinggi dari konsentrasi lainnya. Jumlah daun pada P3 memiliki jumlah daun yang lebih banyak dikarenakan pada P3 mengandung senyawa flavonoid, steroid dan tanin yang lebih tinggi. Ketiga senyawa ini berfungsi sebagai pelindung tumbuhan dari gangguan penyakit maupun lingkungannya, salah satu contohnya yakni perlindungan pada daun dari serangan hama (Lisdawati et al., 2007). Analisis Biomassa tanaman Bayam merah dapat dilihat pada Gambar 3

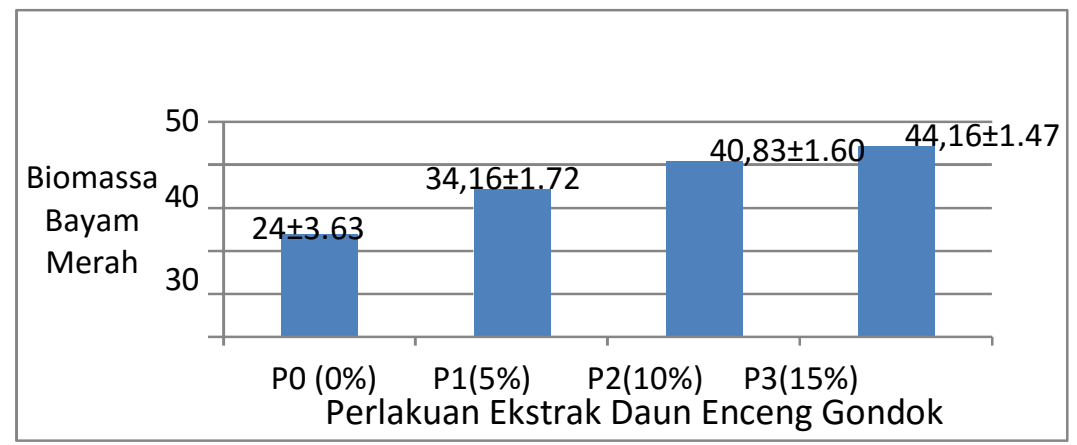

Gambar 3. Diagram jumlah daun tanaman bayam merah (Althernanthera amoena V) setelah diberikan perlakuan bioinsektisida ekstrak daun eceng gondok (Eichhornia crassipes)

Berdasarkan hasil penelitian diketahui bahwa setiap perlakuan dapat menimbulkan pertambahan jumlah daun tanaman yang berbeda-beda. Perlakuan yang paling optimum yaitu bioinsektisida ekstrak daun eceng gondok pada konsentrasi P3 (15\%). Jumlah daun pada P3 memiliki jumlah daun yang lebih banyak dikarenakan pada P3 mengandung senyawa flavonoid, steroid dan tanin yang lebih tinggi. Ketiga senyawa ini berfungsi sebagai pelindung tumbuhan dari gangguan penyakit maupun lingkungannya, salah satu contohnya kini perlindungan pada daun dari serangan hama (Lisdawati et al., 2007). Berdasarkan gambar 3. dapat dikatakan semakin tinggi konsentrasi ekstrak daun eceng gondok dapat meningkatkan produktifitas tanaman bayam merah. Hal ini terjadi karena semakin tinggi kepekatan ekstrak daun eceng gondok semakin banyak pula mengandung senyawa flavonoid,steroid dan tanin. Ketiga senyawa ini mampu melindungi tanaman dari gangguan lingkungan salah satunya yakni organisme pengganggu tanaman. Hal ini berdampak meningkatnya biomassa tanaman bayam merah. (Lisdawatiet al., 2007).

\section{SIMPULAN DAN SARAN Simpulan}

Pemberian perlakuan P3 (15\%) ekstrak daun eceng gondok pengaruh signifikan terhadap jumlah kematian ulat grayak (Spodoptera litura), jumlah daun dan biomassa.

\section{Saran}

Ekstrak daun eceng gondok dapat digunakan sebagai alternatif untuk membasmi hama ulat grayak, meningkatkan jumlah daun tanaman serta bobot tanaman bayam merah dan aman digunakan karena tidak menyebabkan resistensi hama. Untuk pemberian bioinsektisida ekstrak daun eceng gondok

\section{DAFTAR PUSTAKA}

Ajiningrum,P.S. dan Pramushinta, I.A.K. 2017. Pemberian Konsentrasi Bioinsektisida Daun dan Biji Mimba (Azadirachta indica) terhadap Kematian Ulat Grayak (Spodoptera litura). Jurnal Stigma. Vol 10(12):7479. 
Balfas, R., dan M. Wilis.2009. Pengaruh Ekstrak Tanaman Obat terhadap mortalitas dan Kelangsungan Hidup Spodoptera litura F. (Lepidoptera: Noctuidae).

Cahyadi, R. 2009. Uji toksisitas Akut Ekstrak Etanol Buah Pare (Momordika charantia L.) Terhadap Wereng Coklat (Nilaparvata lugens Stal). Jurnal Seminar Nasyonal IX Pendidikan Biologi FKIP UNS, Universitas Ahmad Dahlan Yogyakarta.

Febriyanti, N., dan Rahayu, D.2012. Aktivitas Insektisidal Ekstrak Etanol Daun Kiriyuh (Eupatorium odoratum L.) Terhadap Wereng Coklat (Nilaparvata lugens Stal.). Prosiding Seminar Nasyonal IX Pendidikan Biologi, 9(1): 661-664

Lumowa, S.V.T. dan S. Bardin. 2017. Uji fitokimia kulit pisang kepok (Musa paradisiaca L.) bahan alam sebagai pestisida nabati berpotensi menekan serangan serangga tanaman umur pendek. Jurnal Sains dan Kesehatan. Vol.1(9):465-469.

Lisdawati,V., Sumali, W., Broto, S.K. 2007.Isolasi dan elusidasi struktur senyawa lignin dan asam lemak dari ekstrak daging buah Phaleria macrocarpa. Jurnal Bul Panel Kesehatan ,335(3), 115-124.

Muta'ali R dan Purwani KI.2015. Pengaruh ekstrak daun beluntas (Pluchea indica) terhadap mortalitas dan perkembangan larva Spodoptera litura F. J Sains seni. 4(2):2337-3520.

Razak,TA,T Santhakumar, K Mageswari, and S Santhi . 2014. Studios on efficacy of certain neem products against Spodoptera litura (Fab.). J Biopest 7:160-163.

Suharsono dan M Muchlish A,. 2010. Identifikasi sumber ketahanan aksesi plasma nutfah kedelai untuk ulat grayak Spodoptera litura F. Balai Penelitian Tanaman Kacangkacangan dan Umbiumbian,Malang.Buletin Plasma Nutfah 16(1):29-37.

Sistim, H.O., Tashiro,T.andMotoyama,N. 2009. Reponse of the cutworn Spodoptera litura to sesame leaves of crude extractsin diet. 13pp.J.Insect Sci.9:52.

Wijaya et all. 2016, Screening Fitokimia dan Aktivitas Antioksidan Daun Eceng Gondok (Eicchornia crassipes), Jurnal Kimia Valensi: Jurnal Penelitian dan Pengembangan Ilmu Kimia.Hal65-69.

Winarto L dan Sebayang L.2015. Teknologi pengendalian hama terpadu pada tanaman kubis.Balai Pengkajian Teknologi Pertanian. Sumatra Utara.

Wajhar, A dan R Anggayuhlin.2013. Peningkatan Produktivitas dan Efisiensi Konsumsi Air Tanaman Bayam (Amaranthus tricolor L.) pada teknik hidroponik melalui pengaturan populasi. 